\title{
Tropical Journal of Pathology and Microbiology

\section{A study on prevalence of bacterial isolates causing urinary tract infection at tertiary care hospital, Rajkot, Gujarat, India}

\author{
K Patel P. ${ }^{1 *}{ }^{*}$ H. Pattani M. ${ }^{2}$
}

DOI: https://doi.org/10.17511/jopm.2019.i07.07

1* Priyanka K Patel, Sr. Resident, Department of Microbiology, Rajiv Gandhi Medical College \& CSMH, Mumbai, Maharashtra, India.

2 Manish H. Pattani, Associate Professor, Department of Microbiology, P D U Medical College, Rajkot, Gujarat, India.

Introduction: Urinary tract infection is most common bacterial infectious disease after respiratory tract infection disease in community practice. The introduction of antimicrobial therapy has contributed significantly to the management of UTIs. Objective: This study was conducted to identify bacterial isolates causing urinary tract infection \& their prevalence in different age and gender. Material \& Methods: 1000 Urine Samples received at Tertiary Care Hospital, Rajkot during year 2017 were tested for bacterial pathogen by Culture and Bio-chemical reaction. Results: Out of 1000 samples, $210(21 \%)$ samples were found positive for UTI Isolates. Out of 210 positive cases, the prevalence of UTI was higher in female patients $(56.19 \%)$ than in male patients $(43.81 \%)$. The highest susceptible age group of patients to UTI was found in $21-40$ years $(33.33 \%)$. The highest prevalence of UTI in female patient was found in the age group of $21-40$ years $(44.92 \%)$ while in male patients the highest susceptible age group to UTI was above 60 years (35.87\%). E. coli was the most common isolate $(53.81 \%)$. Conclusion: Present study reported that $E$. coli isolate was the predominant pathogens causing UTI which mainly affected female. The study also allows comparison of the situation in Rajkot with other regions within and outside the state as well as in the country or outside the country. The knowledge of local prevalence of causative uropathogens and their respective antimicrobial sensitivity will help to reduce the incidence of resistance, empirical antibiotic selection in treatment of UTI.

Keywords: Antimicrobial agents, Bacterial isolates, E. coli, Urinary tract infections

Corresponding Author

Priyanka K Patel, Sr. Resident, Department of Microbiology, Rajiv Gandhi Medical College \& CSMH, Mumbai, Maharashtra, India.

Email: drpriyankapatel211@gmail.com
How to Cite this Article

To Browse

Patel PK, Pattani MH. A study on prevalence of bacterial isolates causing urinary tract infection at tertiary care hospital, Rajkot, Gujarat, India. Trop J Pathol Microbiol. 2019;5(7):454-460. Available From

https://pathology.medresearch.in/index.php/jopm/ar ticle/view/288

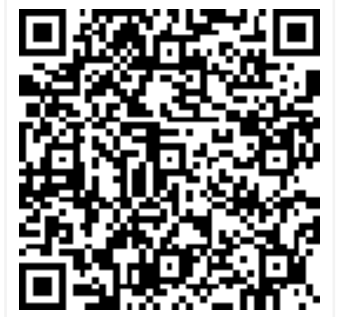

Manuscript Received 2019-06-04

Conflict of Interest No
Review Round 1 2019-06-14

Funding

Nil

Review Round 2
2019-06-20
Ethical Approval
Yes

Review Round 2

Yes
Review Round 3

Plagiarism X-checker $6 \%$
Accepted 2019-06-25

Note

(C) 2019 by Priyanka K Patel, Manish H. Pattani and Published by Siddharth Health Research and Social Welfare Society. This is an Open Access article licensed under a Creative Commons Attribution 4.0 International License https://creativecommons.org/licenses/by/4.0/ unported [CC BY 4.0]. 


\section{Introduction}

Urinary tract infection (UTI) is most common bacterial infectious disease after respiratory tract infection disease in community practice with a high rate of morbidity and financial cost. It has been estimated that 150 million people were infected with UTI per annum worldwide which costing global economy more than 6 billion US dollars. Although UTIs occur in all age groups including men and women, clinical studies suggest that the overall prevalence of UTI is higher in women.

An estimated $50 \%$ of women experience at least one episode of UTI at some point of their lifetime and between 20 to $40 \%$ of women can have recurrent episodes $[1,2]$. UTIs in men are uncommon but often associated with structural or functional abnormality. UTI is more common in females than in males as female urethra structurally found less effective for

Preventing the bacterial entry. It may be due to the proximity of the genital tract, urethra and adherence of urothelial mucosa to the mucopolysaccharide lining [3]. The other main factors which make females more prone to UTI are pregnancy and sexual activity [4]. In pregnancy, the physiological increase in plasma volume and decrease in urine concentration develop glycosuria in up to $70 \%$ women which ultimately leads to bacterial growth in urine [5]. Many different microorganisms can cause UTIs though the most common pathogens causing the simple ones in the community are Escherichia coli and other Enterobacteriaceae, which accounts for approximately $75 \%$ of the isolates.

Although Escherichia coli has been reported as the commonest isolate causing UTI, few authors have reported changing patterns in the prevalence of uropathogens $[6,7]$. The introduction of antimicrobial therapy has contributed significantly to the management of UTIs. In almost all cases of community acquired UTI, empirical antimicrobial treatment is initiated before the laboratory results of urine culture are available; thus, resistance may increase in uropathogens due to frequent misuse of antimicrobials [8]. The prevalence of antimicrobial resistance among urinary pathogens has been increasing worldwide due to aberrant use of antibiotics in practise $[9,10]$. The distribution of antimicrobial susceptibility data of UTI causing microorganisms changes from time to time and from place to place [11].
The susceptibility data provided by regional microbiology laboratories helps to choose the empirical choice of antimicrobials to treat UTI. To the best of our knowledge, less data regarding the bacterial resistance in UTIs from Saurashtra Region of Gujarat State, India, has been documented. Since most UTIs are treated empirically, the criteria for the selection of antimicrobial agents should be determined on the basis of the most likely pathogen and its expected resistance pattern in a geographic area. Therefore, there is a need for periodic monitoring of etiologic agents of UTI and their resistance pattern in the community. This study was undertaken in view of paucity of reports of UTIs in patients of Tertiary Care Hospital, Rajkot (Gujarat State), India. Thereby the study was undertaken to find out the most frequent causative organisms of UTI and sex wise, age group wise prevalence in order to facilitate better treatment and management of UTIs at Tertiary Care Hospital, Rajkot.

\section{Material \& Methods}

Setting: The present study was conducted on urine samples received at Bacteriology laboratory, Department of Microbiology from patients of all age suspected of UTI of Tertiary care Hospital, Rajkot, Gujarat, India

Duration: 2017.

\section{Sample size: 1000 Samples}

Exclusion criteria: There were no exclusion criteria for this study.

Data collection procedure: All Urine samples were studied as per the Performa formulated. The Performa includes serial number, register number, Lab number, age, sex, ward, socio economic status and clinical features of patients, Type of urine sample. In the present study, Blood agar, Nutrient agar \& MacConkey agar were used.

Ethical consideration \& permission: Permission for this study was obtained from the ethical committee.

Sample collection: For collection of urine samples patients were advised to collect a clean catch midstream urine specimen in a sterile, wide mouthed leak proof container supplied by the laboratory and bring to the laboratory as early as possible. For catheterized patients, the catheter tubing was clamped off above the port to allow collection of freshly voided urine. 
The catheter port or wall of the tubing was then cleaned vigorously with $70 \%$ ethanol, and urine sample was aspirated via a needle and syringe. Isolation and identification of bacterial pathogens was done by microscopy and culture methods.

Microscopy:The urine samples were mixed thoroughly, uncentrifuged and examined microscopically for wet mount preparation. This was followed by a Gram's stain.

Culture: A calibrated sterile Nicrome wire loop for the semi-quantitative method was used for the plating. It has a $1.3 \mathrm{~mm}$ diameter to deliver 0.001 $\mathrm{ml}$. A loopful of the well mixed urine sample was inoculated on Blood and Mac - Conkey \& Nutrient agar plates. The plates were then incubated at $37^{\circ} \mathrm{C}$ aerobically for 24 hrs.

They were then examined for bacterial growth. A significant bacterial count was taken as any count equal to or in excess of $100,000 \mathrm{CFU} / \mathrm{ml}$. A less than $100 \mathrm{CFU} / \mathrm{ml}$ were interpreted as negative. Bacterial isolates were identified using conventional biochemical tests.

\section{Results}

Out of the total number of 1000 urine samples included in this study, $210(21 \%)$ urine samples were positive for UTI isolates shown in Table 1.

Table-1: Number of positive isolates.

\begin{tabular}{|l|l|l|}
\hline \multicolumn{1}{|c|}{ Prevalence } & \multicolumn{1}{c|}{ No. of samples } & Percentage (\%) \\
\hline No bacterial pathogen & 790 & 79.00 \\
\hline Positive isolates & 210 & 21.00 \\
\hline Total & 1000 & \\
\hline
\end{tabular}

In present study, the prevalence of UTI was higher in female patient (56.19\%) than in male patient $(43.81 \%)$ in 210 positive isolates. The gender wise prevalence of UTI is shown in Table 2.

Table-2: Gender-wise prevalence of UTI.

\begin{tabular}{|l|l|l|l|}
\hline Gender & $\begin{array}{c}\text { Total No. of samples } \\
(\mathbf{n}=\mathbf{1 0 0 0})\end{array}$ & $\begin{array}{l}\text { Samples for positive isolates in } \\
\text { No. }(\mathbf{n}=\mathbf{2 1 0})\end{array}$ & \\
\hline Male & 486 & 92 & $\begin{array}{l}43.8 \\
1\end{array}$ \\
\hline Female & 514 & 118 & $\begin{array}{l}56.1 \\
9\end{array}$ \\
\hline
\end{tabular}

The highest susceptible age group of patients to UTI was found in $21-40$ years (33.33\%) followed by 41 60 years $(26.19 \%)$, Above 60 years (25.25\%), 010 years $(13.81 \%)$ and $11-20(1.43 \%)$. The highest prevalence of UTI in females was found in the age aroun of 21-40 vears (44.92\%); however; in males
60 years $(35.87 \%)$. The age wise and gender wise prevalence of UTI are shown in Table 3.

Table-3: Age groups and gender wise prevalence of UTI.

\begin{tabular}{|l|l|l|l|l|l|l|l|}
\hline Years & \multicolumn{3}{|c|}{ Female } & \multicolumn{3}{c|}{ Male } & \multicolumn{2}{c|}{ Total } \\
\hline $\begin{array}{l}\text { Age } \\
\text { Group }\end{array}$ & $\begin{array}{l}\text { No. of Cases } \\
(n=118)\end{array}$ & $(\%)$ & $\begin{array}{l}\text { No. of Cases } \\
(n=92)\end{array}$ & $\begin{array}{l}(\%) \\
\text { No. of Cases } \\
(n=210)\end{array}$ & $(\%)$ \\
\hline $0-10$ & 16 & 13.5 & 13 & 14.1 & 29 & 13.8 \\
6 & 1.69 & 1 & 3 & 1.09 & 3 & 1.43 \\
\hline $11-20$ & 2 & 44.9 & 17 & 18.4 & 70 & 33.3 \\
\hline $21-40$ & 53 & 2 & 8 & 8 & 3 \\
\hline $41-60$ & 27 & 22.8 & 28 & 30.4 & 55 & 26.1 \\
& 8 & & 3 & & 9 \\
\hline Above & 20 & $\begin{array}{l}16.9 \\
60\end{array}$ & 5 & 33 & 35.8 & 53 & 25.2 \\
\hline
\end{tabular}

Among total of 210 bacterial uropathogens, 207 $(98.57 \%)$ were Gram negative isolates and 3 (1.43 $8 \%$ ) were Gram positive isolates. Table 4 shows the distribution of gram positive and gram-negative isolates.

Table-4: Distribution of gram-positive and gram-negative isolates

\begin{tabular}{|l|l|l|}
\hline \multicolumn{1}{|c|}{ Isolate } & No. of positive isolates $(\mathrm{n}=\mathbf{1 0 0})$ & Percentage (\%) \\
\hline Gram negative & 207 & 98.57 \\
\hline Gram positive & 3 & 1.43 \\
\hline Total & 210 & 100 \\
\hline
\end{tabular}

Escherichia coli were found the dominant bacteria among all isolated uropathogens with the prevalence rate of $53.81 \%$. The second most prevalent isolate was Klebsiella pneumoniae (32.58\%) followed by Pseudomonas aeruginosa (5.71\%), Proteus mirabilis (3.81\%), Acinetobacter baumannii (1.90\%), Staphylococcus aureus (1.43\%), Providencia spp. (0.48\%) and Proteus vulgaris $(0.48 \%)$. Total positive isolates are shown in Table 5.

Table-5: Distribution of positive isolates.

\begin{tabular}{|l|l|l|}
\hline \multicolumn{1}{|c|}{ Isolates } & No. of positive samples $(\mathbf{n = 2 1 0})$ & $\mathbf{( \% )}$ \\
\hline Escherichia coli & 113 & 53.81 \\
\hline Klebsiella pneumonia & 68 & 32.38 \\
\hline Pseudomonas aeruginosa & 12 & 5.71 \\
\hline Proteus mirabilis & 8 & 3.81 \\
\hline Aceinetobacter baumannii & 4 & 1.90 \\
\hline Staphylococci aureus & 3 & 1.43 \\
\hline Providencia spp & 1 & 0.48 \\
\hline Proteus vulgaris & 1 & 0.48 \\
\hline
\end{tabular}

\section{Discussion}


All studies reported different prevalence rate and according various studies of UTI, the prevalence of UTI are varies periodically and geographically also.

Table-6: Comparison of overall prevalence of UTI with other studies.

\begin{tabular}{|l|c|l|}
\hline \multicolumn{1}{|c|}{ Study } & Year & \multicolumn{1}{|c|}{ Positive isolates (\%) } \\
\hline Mohmmed Akram [12] & 2007 & 10.86 \\
\hline Smita Sood, Ravi Gupta [13] & 2012 & 17.16 \\
\hline Alka Nerurkar [14] & 2012 & 60.00 \\
\hline Rezina Parveen [15] & 2015 & 35.67 \\
\hline Nazreen Khan [16] & 2016 & 36.64 \\
\hline Present Study & 2017 & 21.00 \\
\hline
\end{tabular}

Out of 210 Positive isolates, 118 positive isolates were found in female patient in present study (56.19\%) and Comparisons of gender wise UTI prevalence distributions with other similar studies are shown in Table 7. all the above mentioned studies are comparable with present study for higher prevalence rate of UTI in female patient than male patient.

Table-7: Comparisons of gender wise prevalence of UTI with other studies.

\begin{tabular}{|l|l|l|l|}
\hline \multicolumn{1}{|c|}{ Study } & Year & \multicolumn{1}{|c|}{$\begin{array}{c}(\%) \text { Isolates in } \\
\text { female patient }\end{array}$} & \multicolumn{1}{|c|}{$\begin{array}{c}\text { (\%) Isolates in } \\
\text { male patient }\end{array}$} \\
\hline $\begin{array}{l}\text { Mohmmed Akram } \\
\text { [12] }\end{array}$ & 2007 & 66.66 & 33.34 \\
\hline $\begin{array}{l}\text { Smita Sood, Ravi } \\
\text { Gupta [13] }\end{array}$ & 2012 & 62.42 & 37.58 \\
\hline Alka Nerurkar [14] & 2012 & 57.74 & 42.26 \\
\hline Rezina Parveen [15] & 2015 & 61.33 & 38.67 \\
\hline Nazreen Khan [16] & 2016 & 68.67 & 31.33 \\
\hline Present Study & 2017 & 56.19 & 43.81 \\
\hline
\end{tabular}

In the present study, the highest prevalence of UTI $(44.92 \%)$ in female patients was found in the age group of 21-40 years. However highest prevalence of UTI (35.87\%) in male patient was found in elderly age group (Above 60 Years).

Similar results were observed in other studies and comparisons of studies are shown in table 8. Both studies mentioned in Table 8 are comparable with present study and found that more susceptible age group for UTI prevalence in female are 21-40 Years and susceptible age group for UTI in male patients are above 60 years.
Table-8: Comparison of age groups and genders wise UTI Prevalence with other studies

\begin{tabular}{|l|l|l|l|l|}
\hline \multicolumn{2}{|c|}{ Study } & Year & Age group in years & $\%$ prevalence \\
\hline For female & \multicolumn{3}{|l|}{} \\
\hline Smita Sood, Ravi Gupta [13] & 2012 & $21-40$ & 38.42 \\
\hline Nazreen Khan [16] & 2016 & $21-40$ & 46.49 \\
\hline Present Study & 2017 & $21-40$ & 44.92 \\
\hline For Male & 2012 & Above 60 & 46.92 \\
\hline Smita Sood, Ravi Gupta [13] & 2016 & Above 60 & 23.07 \\
\hline Nazreen Khan [16] & 2017 & Above 60 & 35.87 \\
\hline Present Study &
\end{tabular}

In present study, 207 (98.57\%) were gram negative isolates and $3(1.43 \%)$ were gram positive isolates among 210 Positive cases. All studies mentioned in table 9 had reported higher UTI prevalence rate (> $90 \%$ ) in Gram negative isolates compared to gram positive isolates.

Table-9: Comparisons of distribution of grampositive and gram-negative isolates with other studies

\begin{tabular}{|l|l|l|l|}
\hline \multicolumn{1}{|c|}{ Study } & Year & \multicolumn{1}{|c|}{$\begin{array}{c}\text { Gram-negative } \\
\text { isolates (\%) }\end{array}$} & \multicolumn{1}{|c|}{$\begin{array}{c}\text { Gram- positive } \\
\text { Isolates (\%) }\end{array}$} \\
\hline $\begin{array}{l}\text { Mohmmed Akram } \\
\text { [12] }\end{array}$ & 2007 & 93.00 & 7.00 \\
\hline $\begin{array}{l}\text { Atul Kothari, Vishal } \\
\text { Sagar [17] }\end{array}$ & 2008 & 95.00 & 5.00 \\
\hline Shalini [18] & 2011 & 93.70 & 6.29 \\
\hline $\begin{array}{l}\text { Devanand Prakash } \\
\text { [19] }\end{array}$ & 2013 & 90.30 & 9.68 \\
\hline R Shyamala [20] & 2013 & 98.10 & 1.92 \\
\hline Rezina Parveen [15] & 2015 & 94.40 & 6.61 \\
\hline Present Study & 2017 & 98.60 & 1.43 \\
\hline
\end{tabular}

In present study, Escherichia coli were found most common bacteria among all isolated uropathogens with the prevalence rate of $53.81 \%$ followed Klebsiella pneumoniae (32.58\%), Pseudomonasaeruginosa (5.71\%), Proteus mirabilis (3.81\%), Acinetobacter baumannii (1.90\%), Staphylococcus aureus (1.43\%), Providencia spp $(0.48 \%)$ and Proteus vulgaris (0.48\%). Comparisons of Results with the similar studies are shown in Table 10. All the studies have reported that Escherichia coli were the predominant isolates among the uropethgens causing UTI in the range of $34 \%$ to $68 \%$. 
Table-10: Comparison of positive isolates causing UTI with other studies

\begin{tabular}{|c|c|c|c|c|c|c|c|c|c|c|c|}
\hline Study & $\begin{array}{l}\text { Mohmmed } \\
\text { Akram [12] }\end{array}$ & $\begin{array}{l}\text { Atul Kothari, } \\
\text { Vishal Sagar [17] }\end{array}$ & $\begin{array}{l}\text { Shalini } \\
{[18]}\end{array}$ & $\begin{array}{l}\text { Alka } \\
\text { Nerurkar } \\
{[14]}\end{array}$ & $\begin{array}{l}\text { Smita Sood, Ravi } \\
\text { Gupta [13] }\end{array}$ & $\begin{array}{l}\text { Sanjida } \\
\text { Setu [21] }\end{array}$ & $\mid \begin{array}{l}\text { R } \\
\text { Shyamala } \\
{[20]}\end{array}$ & $\begin{array}{l}\text { Devanand } \\
\text { Prakash [19] }\end{array}$ & $\begin{array}{l}\text { Rezina } \\
\text { Parveen } \\
{[15]}\end{array}$ & $\begin{array}{l}\text { Nazreen } \\
\text { Khan [16] }\end{array}$ & $\begin{array}{l}\text { Present } \\
\text { Study }\end{array}$ \\
\hline Year & 2007 & 2008 & 2011 & 2012 & 2012 & 2013 & 2013 & 2013 & 2015 & 2016 & 2017 \\
\hline Escherichia coli & 61.00 & 68.00 & 64.30 & 34.50 & 61.80 & 54.00 & 61.50 & 42.60 & 64.50 & 49.40 & 53.80 \\
\hline $\begin{array}{l}\text { Klebsiella } \\
\text { pneumonia }\end{array}$ & 22.00 & 17.00 & 20.30 & 11.30 & 6.64 & 14.40 & 17.30 & 18.70 & 11.20 & 7.83 & 32.40 \\
\hline Proteus Spp & - & 5.50 & - & 5.35 & 1.44 & 1.13 & 13.50 & 9.03 & 3.74 & 1.20 & 4.29 \\
\hline $\begin{array}{l}\text { Providencia } \\
\text { spp }\end{array}$ & - & - & - & - & - & - & - & - & - & - & 0.48 \\
\hline $\begin{array}{l}\text { Pseudomonas } \\
\text { aeruginosa }\end{array}$ & 4.00 & - & 9.10 & 2.38 & 4.62 & 4.72 & 5.77 & 21.90 & 9.35 & 3.61 & 5.71 \\
\hline $\begin{array}{c}\text { Acinetobacter } \\
\text { baumannif }\end{array}$ & 3.00 & - & - & - & - & - & - & - & - & 1.80 & 1.90 \\
\hline $\begin{array}{c}\text { Staphylococci } \\
\text { aureus }\end{array}$ & 7.00 & $F$ & 6.30 & 21.40 & 5.49 & 0.43 & 1.92 & 9.86 & - & 9.63 & 1.43 \\
\hline Enterobacter & & 5.30 & - & 13.70 & - & 4.46 & - & 7.10 & 2.80 & 19.30 & - \\
\hline Enterococci & - & 1.50 & - & - & 9.24 & 2.01 & - & - & 5.61 & - & - \\
\hline Citrobacter & - & - & - & 9.52 & 2.31 & 1.48 & - & - & - & 2.40 & - \\
\hline
\end{tabular}

The second common bacteria after Escherichia coli was Klebsiella pneumoniae (32.58\%) in the present study. R Shyamala [20], Rezina Parveen [15], Atul Kothari, Vishal Sagar [17], Mohmmed Akram [12], Sanjida Setu [21] \& Shalini [18] had also reported Klebsiella pneumoniae as second most common bacteria after Escherichia coli with prevalence rate of $17.30 \%, 11.20 \%, 17.00 \%, 22.00 \%, 14.40 \%$ \& $20.30 \%$ respectively.

These studies are comparable and similar to present study where Klebsiella pneumoniae was second most common bacteria after Escherichia coli. Prevalence of other isolates likes Pseudomonas aeruginosa, Proteus Spp. Acinetobacter baumannii, Staphylococcus aureus \& Providencia spp. were low in present study.

\section{Conclusion}

Against the background of paucity of reports of UTI in Rajkot (Gujarat), India, this study conducted to determine the prevalence of UTI, the effect of gender and age on its prevalence in community of Rajkot city at Tertiary Care Hospital. In the present study, as expected, the prevalence of UTI was found higher in female patients than male patients. The culture positive rate for UTI uropathogens was also highest in adult female patients with Age group (2140 years) while in male patients, the highest UTI prevalence was found elderly age group (Above 60 Years).
The gram-negative bacilli (Enterobacteriaceae) were responsible for majority of Urinary tract infections. Escherichia coli were found to be the most common isolated bacteria causing urinary tract infection.

\section{What this study adds to existing knowledge?}

This study will help to improve treatment recommen-dations in a specific geographical region. The study also allows comparison of the situation in Rajkot with other regions within and outside the state as well as in the country or outside the country.

\section{Author's contribution}

- Priyanka K. Patel: Concept, Design, Preparation \& editing of manuscript, Data Collection, Data Compiling, Literature Review, Sample Testing and Result Analysis, Final Approval.

- Dr. Manish H. Pattani: Manuscript editing, Literature Review, Final Approval.

\section{Acknowledgement}

Authors would like to thank all clinicians for providing clinical details of all patients \& to laboratory staff for their support for the study. 


\section{Reference}

01. Rock W, Colodner R, Chazan B, Elias M, Raz R. Ten years surveillance of antimicrobial susceptibility of community-acquired Escherichia coli and other uropethogens in northern Israel (1995-2005) Isr. Med Assoc J. 2007;9(11)803-5. [Crossref][PubMed] [Google Scholar]

02. Vasquez Y, Hand WL. Antibiotic susceptibility patterns of community acquired urinary tract infection isolates from female patients on the US (Texas)-Mexico Border. J Appl Res. 2004;4(2)321-6. [Crossref][PubMed][Google Scholar]

03. Schaeffer AJ, Rajan N, Cao Q. Host pathogenesis in urinary tract infections. International Journal of Antimicrobial Agents. 2001;17(4)245-251. DOI: 10.1016/S09248579(01)00302-8 [Crossref][PubMed][Google Scholar]

04. Arul KC, Prakasam KG, Kumar D, and Vijayan M. A cross-sectional study on distribution of urinary tract infection and their antibiotic utilization pattern in Kerala. Int $\mathrm{J}$ Res Phamaceut Biomed Sci. 2012;3(3)1125-1130. [Crossref][PubMed][Google Scholar]

05. Gonzalez CM and Schaeffer AJ. Treatment of urinary tract infection- what's old, what's new and what works. World J Urol. 1999;17(6)372-382. [Crossref][PubMed][Google Scholar]

06. Omoregie R, Erebor JO, Ahonkhai I, Isobor JO, Ogefere HO. Observed changes in the prevalence of uropathogens in Benin City, Nigeria. NZJ Med Lab Sci. 2008;62;29-31. [Crossref][PubMed][Google Scholar]

07. Omoregie R, Eghafona NO. Urinary tract infection among asymptomatic HIV patients in Benin City, N gria. Br J Biomed Sci. 2009;66;190-3. DOI: 10.1080/09674845.2009.11730272

[Crossref]

[PubMed][Google Scholar]

08. Tambekar DH, Dhanorkar DV, Gulhane SR, Khandelwal VK, Dudhane MN. Antimicrobial suscepti-bility of some urinary tract pathogens to commonly used antibiotics. Biotechnol. 2006;5(17)1562-5. [Crossref][PubMed][Google Scholar]

09. Bonadio M, Meini M, Spetaleri P, Gilgi C. Current microbiological and clinical aspects of urinary tract infections. Eur J Urol. 2001;40(4)439-45. [Crossref] [PubMed][Google Scholar]
10. Grude N, Tveten $Y$, Kristiansen BE. Urinary tract infections in Norway- bacterial etiology and susceptibility, a retrospective study of clinical isolates. Clin Microbial Infect. 2001;7(10)543-7. DOI: $10.1111 / j .1469-0691.2001 .00306 . x$ [Crossref] [PubMed][Google Scholar]

11. McNulty CA, Richards J, Livermore DM, Little P, Charlett $A$, Freeman $E$ et al. Clinical relevance of laboratory-reported antibiotic resistance in acute uncomplicated urinary tract infection in primary care. J Antimicrob Chemotherap. 2006;58(5)10001008. DOI: 10.1093/jac/dk/368 [Crossref][PubMed] [Google Scholar]

12. Akram M, Shahid M, Khan AU. Annals of Clinical Microbiology and Antimicrobials, Etiology and antibiotic resistance patterns of community acquired urinary tract infections in JN MC hospital Aligarth, India. Ann Clin Microbiol Antimicrob. 2007;6(4)1-7. [Crossref][PubMed][Google Scholar]

13. Sood S, Gupta R. Antibiotic Resistance Pattern of Community Acquired Uropathogens at a Tertiary Care Hospital in Jaipur, Rajasthan. Indian J Commun Med. 2012;37(1)39-44. DOI: 10.4103/09700218.94023 [Crossref][PubMed][Google Scholar]

14. Nerulkar A, Solanky P, Naik SS. Bacterial path ogens in urinary tract infection and antibiotic susce ptibility pattern. J Pharmaceut Biomed Sci. 2012; 21(12)1-3.[Crossref][PubMed][Google Scholar]

15. Parveen R, Md Yushuf A, Sharmin I, Md Islam S, Rahim I. Antibiotic Sensitivity of Bacteria Causing Urinary Tract Infection Bang. J Infect Dis. 2015;2(1)13-18. DOI: 10.3329/bjid.v2i1.31324 [Crossref][PubMed][Google Scholar]

16. Nazreen Khan, Mohd Shahid khan. Prevalence of Antimicrobial Resistance in Bacterial Isolates causing Urinary Tract Infection in Patients attending IIMS \& R Hospital, Lucknow. Int J Life Sci \& Scientific Res. 2016;2(1)1-8. [Crossref][PubMed] [Google Scholar]

17. Kothari A, Sagar V. Antibiotic resistance in pathogens causing community acquired urinary tract infection in India: a multicentre study. J infect Developing Countries. 2008;2(5)354-358. [Crossref][PubMed][Google Scholar]

18. Shalini, Joshi MC, Rashid MK, Joshi HK. Study of Antibiotic Sensitivity Pattern in Urinary Tract Infection at a Tertiary Hospital. Nat J Integ Res Med. $2011 ; 2(3) 43-46$. Scholar]
[Crossref][PubMed][Google 
19. Prakash D, Saxena RS. Distribution and antimicrobial susceptibility pattern of bacterial pathogens causing urinary tract infection in urban community of Meerut City, India. ISRN Microbiology. 2013. DOI: 10.1155/2013/749629 [Crossref] [PubMed][Google Scholar]

20. Shyamala R, Ravinder N, Shazia Parveen, Janardhan Rao. Escherichia coli as the commonest uropethogen in a tertiary care hospital. J Microbiol Biotechnol Res. 2013;3(6)49-51. [Crossref] [PubMed][Google Scholar]

21. Setu SK, Sattar AN, Saleh AA, Roy CK, Ahmed $M$, Muhammadullah $S$, et al. Study of Bacterial pathogens in Urinary Tract Infection and their antibiotic resistance profile in a tertiary care hospital of Bangladesh. Bangladesh J Med Microbial. 2016;10(1)22-26. DOI: 10.3329/bjmm.v10i1.31449 [Crossref][PubMed][Google Scholar] 